\title{
Research on Financial Management of Research- based Universities Under the Guidance of the Education Strategy in 19th CPC National Congress
}

\author{
Based on the Perspective of Contingency Management
}

\author{
Jing Chen \\ Finance Office \\ Southwest University \\ Chongqing, China 400700
}

\begin{abstract}
Under the guidance of the education strategy of 19th National Congress of CPC "Promoting Development by governance", it is bound to trigger the resonance of researchbased universities and affect their financial governance behavior. Based on the education strategy of 19th CPC National Congress and the contingency management thought, this paper discusses and analyzes its impact on the financial management of research-based universities, and proposes financial governance suggestions for adapting to the new management environment, in order to promote the financial management level of research-based universities.
\end{abstract}

Keywords-research-based universities; contingency management concept; financial governance; suggestion

\section{INTRODUCTION}

Education is an important part of socialism with Chinese characteristics. China has a unique history, culture and national conditions, which determines that China must follow its own path of higher education development. In October 2017, report of 19th CPC National Congress put forward the educational strategy of "strengthening and innovating the level of university governance and realizing the connotative development of higher education" [1]. The governance ability of university is an inevitable requirement for improving the quality of higher education. It is a necessary requirement of 19th CPC National Congress for higher education to take the connotative development path with the core of improving quality. Financial governance is the guarantee of governance ability of universities, which is directly related to the governance level of universities and the realization of the school's connotative development goals.

Research-based universities are not only the center of the highest level personnel training and the latest cutting-edge science and technology research and development in China, but also the main front for implementing the education strategy of 19th CPC National Congress and play an important role in social governance construction. [2] With the continuous advancement of China's education system reform, the catalysis of marketization factors for researchbased universities has become more and more obvious. It has gradually become a legal entity that runs school independently facing the society. With the diversified internal economic development and increasingly complex external economic relations, the funds for running schools are no longer dominated by single financial allocation, and diversified financing channels are gradually taking shape. Changes in the internal and external financial management environment, especially under the guidance of the education strategy of 19th CPC National Congress, require researchbased universities to further standardize financial governance so that they can better serve socialism education with Chinese characteristics. In view of the positive role of financial governance, this paper, based on the contingency management theory, explores the impact of the new educational environment and environment requirements on the financial governance behavior of research-based universities and the countermeasures based on the education strategy of 19th CPC National Congress, in order to promote the improvement of financial governance level of research universities.

\section{THE EFFECT OF MECHANISM}

The contingency management theory holds that the internal factors and external environmental conditions of each organization are different. Therefore, there are no principles and methods applicable to any situation in management activities, which means in management practice, the methods should be changed according to the environment of the organization and the development of internal conditions, and there is no consistent and universally applicable management method. Furthermore, the management behavior in different situations should be diverse, and the government can use multiple means such as the system to promote the change of micro-organization management. Therefore, the education strategy of 19th CPC National Congress put forward new requirements for the governance of colleges and universities, which will inevitably lead to resonance of research-based universities and influence the financial governance behaviors to change significantly. 
For a long time, China's colleges and universities have implemented the principal responsibility system under the leadership of the party committee. Both financial right and personnel rights are deeply influenced by the education and financial departments. It is necessary to carry out various tasks under the guidance of the educational policy of the party. Under the guidance of the education strategy of 19th National Congress of CPC "Promoting Development by governance", it will inevitably lead to a wide range of responses and positive imitations at the university level, including research-based universities. The education strategy of 19th CPC National Congress puts forward new requirements for financial governance behaviors such as organizational functions, interest distribution, governance structure, and performance evaluation, etc., which requires research-based universities to conduct "contingency" management in order to meet and balance the needs of internal financial governance and adapt to environmental conditions. In other words, research-based universities are complex systems that are influenced by the environment. Therefore, research-based universities must adopt appropriate financial governance measures in accordance with the changing environment to maintain the best adaptation to the environment. It can be seen that after the introduction of the education strategy of 19th CPC National Congress, the new educational environment is about to be formed, which will lead to the emergence of "contingency" in research-based universities and drive the radical changes in financial governance behavior.

\section{THE ANALYSIS OF IMPACT}

The organizational environment is an important variable that affects the financial behavior of different entities. The educational strategy proposed by 19th CPC National Congress in 2017 essentially requires research-based universities to regulate the financial behavior of colleges and universities and coordinate their own rights and responsibilities, which make them face a new financial governance environment and also determines the foothold and starting point of financial governance [3]. After combing, the requirements of the education strategy of 19th CPC National Congress for the financial governance of researchbased universities are mainly reflected in the four aspects of scientific organization, rational distribution of benefits, systemic governance structure, and lean performance evaluation, as shown in "Table I".

TABLE I. REQUIREMENTS OF THE EDUCATION STRATEGY OF 19TH CPC NATIONAL CONGRESS FOR THE FINANCIAL MANAGEMENT OF RESEARCH-BASED UNIVERSITIES

\begin{tabular}{|c|l|}
\hline $\begin{array}{c}\text { Governance } \\
\text { framework }\end{array}$ & $\begin{array}{l}\text { General requirements for the education strategy of 19th } \\
\text { CPC National Congress }\end{array}$ \\
\hline $\begin{array}{c}\text { Organization } \\
\text { al function }\end{array}$ & $\begin{array}{l}\text { Transform functions, innovate supervision, and build } \\
\text { service-oriented institutions. }\end{array}$ \\
\hline $\begin{array}{c}\text { profit } \\
\text { distribution }\end{array}$ & $\begin{array}{l}\text { comprehensively use various types of resources to form a } \\
\text { scientific and rational resource management system. }\end{array}$ \\
\hline $\begin{array}{c}\text { Governance } \\
\text { structure }\end{array}$ & $\begin{array}{l}\text { comprehensively consider various institutional settings, } \\
\text { scientifically allocate departmental authority, and clarify } \\
\text { responsibilities. }\end{array}$ \\
\hline $\begin{array}{c}\text { Performance } \\
\text { Evaluation }\end{array}$ & $\begin{array}{l}\text { Accelerate the formation of a performance evaluation } \\
\text { system that promotes high quality development. }\end{array}$ \\
\hline
\end{tabular}

\section{A. Scientific Financial Function}

The education strategy in the report of 19th CPC National Congress proposed the overall requirements for transforming functions, which emphasizes "transforming functions, innovating supervision, and building serviceoriented institutions". The above new requirements will inevitably lead to the trend of the transformation of financial functions in research-based universities. The financial functions of previous research-based universities pay much attention to "management", but can't give full play to the function of "services". This is because the financial management of research-based universities is mainly handled by the deputy principal or chief accountant. Major financial matters are determined by the party committee or the school committee. The members of these institutions are mainly managers appointed by government, lacking representatives of other stakeholders such as scientific research workers and experiments. Therefore, they often emphasize rigid management style but lack service awareness in decision-making and work. With the diversification of fund sources of research-based universities, their finance departments not only need to perform management functions, but also should reflect a more important function in the financial function, which is the service function. The service function occupies an indispensable seat in financial function of research-based universities in the future.

\section{B. Rationalization of Interest Distribution}

Due to the large number of secondary departments in research-based universities and the competition for interests, it is easy to see a phenomenon of low capital allocation and use efficiency. [4] The requirement of rationalized interest distribution in the report of 19th CPC National Congress stresses the "comprehensive use of various types of resources to form a scientific and rational resource management system", which is conducive to the development of a new pattern of interest distribution in research-based universities At present, the distribution effect of some research-based universities is not optimistic, which is mainly reflected in that the phenomenon of competition for funds in various departments is serious, the proportional relationship between school material resources structure is not coordinated, and the distribution of assets is improper; the funds of major expenditure items are often managed in blocks by school leaders in charge of infrastructure, equipment, and logistics and related functional departments. This will easily lead to major expenditure items such as laboratory construction and key disciplines to attend to one thing and lose another and to begin well but end badly, or lead to repeated construction and waste, making it difficult to achieve overall planning and ensure key points. In the new environment, the past nonefficiency benefit distribution behavior can be considered, forcing research-based universities to have to re-examine the problem of traditional low capital using efficiency and explore a more reasonable benefit distribution model. 


\section{Systematization of Governance Structure}

With the diversification of the main body of higher education and the interaction of academic power, market power and government power, the governance structure of research-based universities has been tested. The report of 19th CPC National Congress puts forward the governance requirements of "comprehensively considering the establishment of various institutions, scientifically allocating department powers, and clarifying responsibilities". It is necessary for research-based universities to choose governance structure as a breakthrough in system reform, weaken the drawbacks of financial governance structure, and promote the effectiveness of financial rights arrangements and implementation in colleges and universities. At present, there are multiple complex principal-agent relationships between the administrators of colleges and universities, especially the public research-based universities, and the owners of the schools. It is easy for internal managers to use their powers to maximize their own interests, damage the interests of college teachers and students, and weaken the ownership interest of colleges and universities and public beneficial internal control issues of higher education. As a basic framework for restricting the internal financial power and management capital arrangement, the governance structure of research-based universities urgently needs to comply with the new requirements of the governance structure of the education strategy in 19th CPC National Congress report and explore a new path to improve the level of financial governance.

\section{Lean Performance Evaluation}

The education strategy in the report of 19th CPC National Congress mentioned "accelerating the formation of a performance evaluation system that promotes high-quality development", which puts forward new requirements for the lean performance evaluation of research-based universities. For research universities, the overall performance depends on the individual performance of teachers in the system, so the lean performance evaluation must be placed in the performance evaluation of teachers and researchers. For a long time, the research management efficiency of some research-based universities has paid insufficient attention to the performance of teachers' scientific research. As a result, the relationship between cost and benefit has been neglected in the process of using scientific research funds, which results in the unreasonable allocation of scientific research funds and even losses and huge waste. At the same time, the performance evaluation mode in some research-based universities is based on static results. The input/output, efficiency/effects are rarely tracked and judged, and the evaluation accuracy is low, which restricts the improvement of scientific research efficiency and work enthusiasm of internal teachers. The education strategy of 19th CPC National Congress requires the evaluation of the performance of research-based universities from the lean perspective, which is beneficial to the rational evaluation of scientific research performance, the promotion of teachers' scientific research ability, and the promotion of school's innovative development.

\section{CORRESPONDING SUGGESTIONS}

The more education develops, the more necessary financial governance is. Under the guidance of the education strategy connotation in 19th CPC National Congress "promoting development with governance", research-based universities must pay attention to their own financial governance work, and actively respond to it to promote the improvement of financial governance based on focusing on the scientized financial functions, rationalized interest distribution, systematization of governance structure, and lean performance evaluation.

\section{A. Realizing the Organic Combination of Financial Management and Service}

Under the advocacy of scientific financial functions, all functional service departments and related personnel of research-based universities should fully realize that service is their duty and obligation, so they should serve the school's key work and improve service quality with the purpose of serving. Financial staff should firmly establish service awareness and abide by the professional ethics of accountants. The finance department should strengthen publicity and training for financial personnel and strengthen their service awareness to make service awareness a prescribed action in thinking, so that financial personnel can actively consider the needs of service objects, form the service thinking subconsciously and embody it in action, and can consciously put into service behavior, thus providing high-quality services. At the same time, Financial personnel should take the lead to oppose the "four customs", improve their work style, provide the same services regardless of the official duties and identities, provide quality services to the clients objectively and fairly, and combine management and services to create a harmonious financial atmosphere and build a harmonious financial relationship.

\section{B. Improving the Use Efficiency of Financial Resources}

Under the guidance of the concept rationalizing benefit distribution in 19th CPC National Congress, research-based universities need to pay attention to the issue of internal interest distribution and strive to improve the efficiency of financial resources. First, research-based universities should strengthen budget management and control the implementation process of the budget so that it cannot only reflect the data according to historical experience of the financial management department and combine the developing scale and speed of the planned educational undertakings with the scientific funding needs and supply quantity forecast made by corresponding adjustments, but also optimize the allocation of budget funds according to the basic principles of budget preparation. At the same time, they should consider from the aspects of solvency, asset utilization, efficiency, and development capability, etc. to timely grasp the utilization and efficiency of the school's personnel, financial, and material resources, and establish a scientific and sound financial analysis indicator system to improve the financial management of the school and provides specific measures and ways for schools to further strengthen and improve financial management, increase 
income, reduce consumption, save expenditures, eliminate waste, and continuously improve the use efficiency of funds.

\section{Improving the Decision-making Mechanism of Financial Governance}

Under the guidance of the systematization of governance structure, from the perspective of financial governance structure, the position of the board of directors is the highest leading body for affairs decision-making in research-based universities. The functional power of the financial management of the board of directors includes the responsibility to review and formulate the school's development strategy, formulate the school's financial budget and final settlement plan, propose the school's financial management system and establish an effective incentive and restraint mechanism; it is obliged to supervise major economic activities and economic decision-making and report to the government and stakeholder representatives, review and submit the school's financial reports and audit reports, approve and judge on-campus complaints, communicate with society, and fully realize the balance in right, responsibility, and profit of various stakeholders in financial activities of research-based universities.

\section{Promoting Lean Performance Evaluation}

The existing research performance evaluation methods of teachers in research-based universities are outdated and the index system is single, which is difficult to stimulate the teachers of research-based universities. Lean performance evaluation requires research-based universities to not only establish evaluation methods and indicators that are in line with the school's strategic goals, but also classify and evaluate teachers' research results of different disciplines. At the same time, it must conform to the internationalization and globalization of higher education, encourage foreign teachers of research-based universities to devote themselves to scientific research, strengthen international scientific research cooperation, adopt effective evaluation methods and index systems to evaluate the scientific research performance of foreign teachers, and stimulate the enthusiasm of school teachers, thus improving the comparative advantage of higher education in China and contribute more power to economic construction and cultural prosperity. At the same time, research-based universities should also pay attention to the limitations of scientific research performance evaluation indicators, and timely correct the deviation between evaluation results and actual performance. To this end, it is necessary to comprehensively use quantitative and qualitative research performance evaluation methods to objectively measure teachers' scientific research results, so as to create a fair and good research atmosphere for teachers.

\section{CONCLUSION}

The connotation of the education strategy in 19th CPC National Congress "promoting development with governance" has a positive impact on the financial governance of research-based universities, which will lead to "contingency" in its financial governance. This paper focuses on the essential requirements of 19th CPC National Congress on the financial management of colleges and universities and analyzes the existing influences and countermeasures based on the contingency theory. The research conclusion indicates that the education strategy of 19th CPC National Congress puts forward new requirements of scientific organizing function, rationalized interest distribution, systematized governance structure, and lean performance evaluation for financial governance of research-based universities. They should actively respond to it, strive to realize the organic combination of financial management and service, improve the use efficiency of financial resources, complete the decision-making mechanism of financial governance, and promote lean performance evaluation. The conclusion of this paper has positive significance for the financial theory of non-profit organizations and the governance practice of research-based universities.

\section{REFERENCES}

[1] Xi Jinping. Report of Xi Jinping at the 19th National Congress of the Communist Party of China [EB/OL] http://www.china.com.cn/19da/2017-10/27/content_41805113.htm.

[2] Wang Shulan. Promote the reform and innovation of local colleges and universities with reversed mechanism [J]. Management World, 2010, (05): 174-175.

[3] Zhang Yun. Research on Financial Governance of Public Universities under the Vision of Constructing Modern University System[J]. The Chinese Certified Public Accountant, 2012(10): 71-73.

[4] Zhang Zhonghua. On the Financial Management Innovation and construction of Financial Risk Prevention Mechanism in Colleges and Universities[J]. Public Finance Research, 2016(05):58-59. 